\title{
Ferrous Complexes with Bis (Meo) in A- Substituted Tris (Pyridin-2-Ylmethyl) Amine Ligands: Effect of the Bis (Meo) in A- Substituents in Dioxygen Activation and Biomimetic Reactivity
}

\author{
Nasser Thallaj
}

\begin{abstract}
This report describes how the coordination of $\mathrm{FeCl}_{2}$ with tris(pyridin-2-ylmethyl)amine (TPA) ligands offers the possibilty to activate the molecular dioxygen in biomimetic processes. . It includes all procedures taken to the case for major oxidation reactions carried out in Nature under particular conditions. The aim of the this paper is to present the outcome of a thorough study for complex coordinations with ligands substituted by groups known as electron donors. It demonstrates how ligands with methoxy substituents are likely to be demethylated, and therefore providing entities potentially useful in synthesis. Targeting in modulating the electronic properties at the metal center, a new type of ligand $(\mathrm{MeO})_{2} \mathrm{TPA}$ has been prepared and the complex of (MeO)2TPAFeCl ${ }_{2}$ has been studied by uv-visble ; 1H RMN paramagnatic and conductometry. The effect of (MeO) group in $\alpha$-substituted on the structure as well as the effect of substitution on the oxygenation of the complex has been verified. Afterwards, the reactivity of the complex towards molecular dioxygen in absence of substrat is checked by uvvisble, ${ }^{1} \mathrm{H}$ RMN paramagnatic and radiocristallography. As well, the reactivity in presence of substrat is tested.
\end{abstract}

Keywords: Biomimetic, tris(pyridin-2-ylmethyl)amine, $(\mathrm{MeO})_{2} \mathrm{TPA},(\mathrm{MeO})$ in $\alpha$-substituted,iron ${ }^{(I I)}$, Molecular dioxygen activation.

\section{INTRODUCTION}

$\mathrm{H}_{\text {ydroxylation reactions, which take place in the }}$ presence of molecular oxygen, ferrous iron and tetrahydrobiopterin (BH4) [1], are found in several biological processes. Tryptophan hydroxylase (TrpH), catalyzes the transformation of L-Tryptophan to 5Hydroxytryptophan (Serotonin, 5-HT) as shown in Figure 1, Serotonin is known to play important roles in many biological functions [1-8]. Due to the sequential and structural homology and the similarity of the chemical transformations occurring by phenylalanine hydroxylase (PAH),Tyrosine hydroxylase (TyrH), and Tryptophan hydroxylase (TrpH), it is commonly believed that these three enzymes have a similar hydroxylation mechanism [1,9-13].

Manuscript received on 14 September 2021 | Revised Manuscript received on 25 September 2021 | Manuscript Accepted on 15 October 2021 | Manuscript published on 30 October 2021.

* Correspondence Author

Dr. Nasser K Thallaj", Assistant Professor of Chemistry at Faculty of Pharmacy, Damascus, Syria.

(c) The Authors. Published by Lattice Science Publication (LSP). This is an open access article under the CC-BY-NC-ND license (http://creativecommons.org/licenses/by-nc-nd/4.0/)

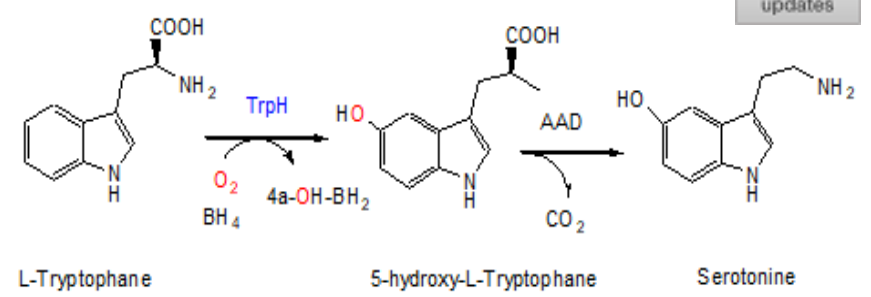

Figure 1: Conversion of L-Tryptophan to 5hydroxytryptophan by Tryptophan hydroxylase (TrpH).BH4: tetrahydrobiopterin; 4a-OH-BH2:

hydroxydihydrobiopterin; AAD:Aromatic amino acid decarboxylase.

Previously, mechanistic studies have demonstrated that FeII center and organic cofactor are required for aromatic hydroxylation to occur $[9,14]$. So far, the study of catalytic mechanisms have relied mainly on kinetic analyzes, including the study of isotopic effects. It was deduced that dioxygen had the ablity to bridge the active site and the hydroxylated carbon of pterin. Investigations have been carried out on TyrH in the presence of oxygen ${ }^{18} \mathrm{O}_{2}$ [15], and have suggested the absence of Fe-oxy as an intermediate. It is postulated that molecular oxygen coordinates weakly, rather on a hydrophobic site of the protein between iron and pterin. These results, in combination with previous studies indicate that electron transfer from $\mathrm{BH} 4$ to oxygen forms a superoxide anion as the first reactive intermediate. This radical pair would then couple to form an intermediate of type 4a peroxytetrahydropterin. The position of pterin relative to the active iron site, as observed in the structures of the three hydroxylases [12,16,17], suggests that the intermediate of $4 \mathrm{a}$ peroxytetrahydropterin can then coordinate by forming a bridge with iron, which has moreover been proposed by several groups [18-22] (Figure 2). The iron peroxyplerin formed will later be transformed by heterolytic cleavage into 4a-HO-BH2 and $\mathrm{Fe}^{\mathrm{VI}}$-oxo, which would then be responsible for the hydroxylation of the amino acid. 


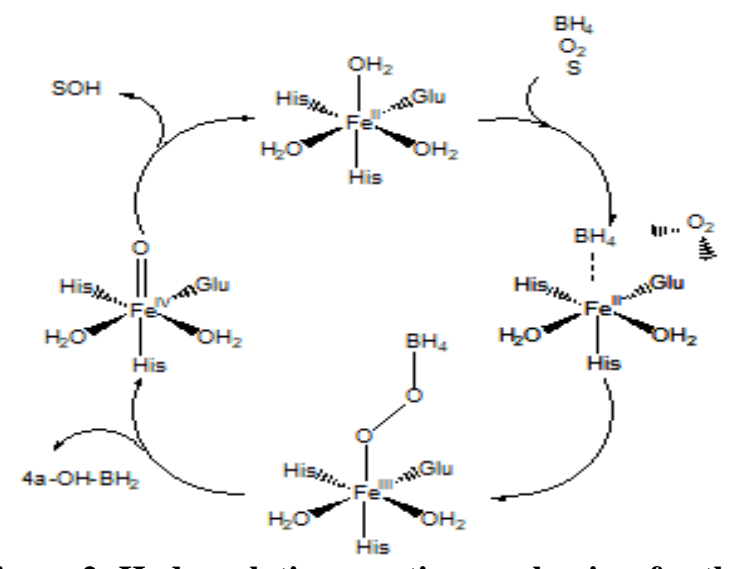

Figure 2: Hydroxylation reaction mechanism for the three hydroxylases, according to reference 16.

\section{MATERIALS AND METHODS}

A. Synthesis of 2-methoxy-6-Methylpyridine [26]. : $6.10 \mathrm{~g}$ (153mmoles) of $60 \% \mathrm{NaH}$ are washed with hexane and the mineral oil is extracted several times under argon until obtaining $\mathrm{NaH}$ without oil (pure $\mathrm{NaH}$ ). $12 \mathrm{~g}$ (70mmoles) of 2-Bromo-6-Methylpyridine are dissolved in $80 \mathrm{ml}$ of DMF, the solution is added to the $\mathrm{NaH}$ gradually over 15 minutes. The temperature of the medium is adjusted to $0{ }^{\circ} \mathrm{C}$ using an ice bath under argon. The medium becomes very thick and the temperature does not exceed $0^{\circ}$ C. $6.1 \mathrm{~cm} 3$ (153mmol) of methanol are added gradually over 5 minutes. The reaction mixture is refluxed for 3 hours at 80 $\circ \mathrm{C}$. The solution obtained is allowed to cool to room temperature. The product is extracted several times with ether. At the end, the transparent pale yellow solution obtained is washed several times with distilled water. Then, the organic phase is dried over MgSO4 then filtered and evaporated. This transparent pale yellow liquid is distilled under reduced pressure ( $\mathrm{P}=15 \mathrm{mmHg})$. The fraction of the desired product was collected between 80 and $85^{\circ} \mathrm{C}$, it is a colorless liquid.

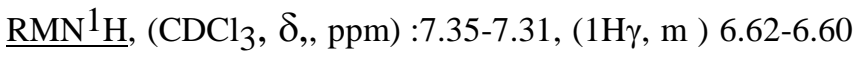
$(1 \mathrm{H} \beta, \mathrm{d}, \mathrm{J}=6)$; 6.48-6.45 (1H $\left.\beta^{\prime}, \mathrm{d}, \mathrm{J}=9\right)$; 3.86, ( s, 3H, $\left.\mathrm{OCH}_{3}\right)$; 2.28, (s, $\left.3 \mathrm{H}, \mathrm{CH}_{3}\right)$.

\section{B. Synthesis of 2-methoxy-6-Bromomethylpyridine} [26]:

Into a solution of 2-methoxy-6-methyl pyridine (12g, 97.5 mmoles) in $200 \mathrm{ml}$ of carbon tetrachloride CCl4 are introduced $20.82 \mathrm{~g}$ of N-bromosuccinimide (117.3 mmoles) and $675 \mathrm{mg}$ of azobisisobutyronitrile (2.79 mmoles). The reaction mixture is brought to reflux ( $90^{\circ} \mathrm{C}$.) for 5 hours. At the end, the solution is evaporated to dryness. The product taken up in $200 \mathrm{ml}$ of toluene. The precipitate which forms is filtered off and the yellow solution is concentrated. The product is purified by chromatography column on silica mounted in toluene. The separation is followed by thin layer chromatography (TLC). This is the third fraction that contains the desired product. The product 2-methoxy-6Bromomethylpyridine is a transparent liquid obtained with a yield of 50\% (mass obtained: $9.85 \mathrm{~g}$ )

$\underline{\mathrm{RMN}^{1} \mathrm{H}}:\left(\mathrm{CDCl}_{3}, \delta, \mathrm{ppm}\right)$ 7.54-7.47, (t,1H) 6.96-6.96 $(\mathrm{d}, 1 \mathrm{H}) ; 6.64-6.61(\mathrm{~d}, 1 \mathrm{H}) ; 4.43,(\mathrm{~s}, 2 \mathrm{H}) ; 3.91(\mathrm{~s}, 3 \mathrm{H})$.
Synthesis of 1-(5-methoxypyridin-2-yl)- $N-((6-$ methoxypyridin-2-yl)methyl)- $N$-(pyridin-2-

ylmethyl)methanamine)

((MeO) 2TPA): 2 g (9.9 mmol) of 2- (bromomethyl) -6methoxypyridine and $0.925 \mathrm{~g}(4.95 \mathrm{mmol})$ of 2picolylamine are introduced into a flask. About $2 \mathrm{~g}$ of $\mathrm{Na} 2 \mathrm{CO} 3$ and about $200 \mathrm{ml}$ of ethanol are added. The medium is heated under reflux for 14 hours at $95^{\circ} \mathrm{C}$. The treatment procedure is identical to that for $(\mathrm{MeO}) \mathrm{TPA}$. The product is purified by chromatography on an alumina column mounted with DCM containing 10\% methanol. (MeO) 2TPA has an orange-brown color and has a very hygroscopic character (Yield: 80\%, mass obtained: $1.697 \mathrm{~g}$ ). Elemental analysis: Calculated for $\left(\mathrm{C}_{20} \mathrm{H}_{22} \mathrm{~N}_{4} \mathrm{O}_{2}\right)$. C : 68,65; $\mathrm{H}: 6,33 ; \mathrm{N}: 1,99$.

Calculated for $\left(\mathrm{C}_{20} \mathrm{H}_{22} \mathrm{~N}_{4} \mathrm{O}_{2}\right) 3+\mathrm{H}_{2} \mathrm{O}: \mathrm{C}: 67,40 ; \mathrm{H}: 6,41$; $\mathrm{N}: 15,72$.

Obtained for ((MeO) $)_{2}$ TPA $) 3 \cdot \mathrm{H}_{2} \mathrm{O}$. C : 67,89 ; $\mathrm{H}: 6,342$; $\mathrm{N}: 15,51$.

$\underline{\mathrm{RMN}}{ }^{1} \mathrm{H}\left(300 \mathrm{MHz}, \mathrm{CDCl}_{3}\right): \delta(\mathrm{ppm}) 3,83\left(\mathrm{~s}, 4 \mathrm{H}, 2 \mathrm{CH}_{2}\right)$; $3,85\left(\mathrm{~s}, 6 \mathrm{H}, 2 \mathrm{CH}_{3}\right) ; 3,98\left(\mathrm{~s}, 2 \mathrm{H}, \mathrm{CH}_{2}\right) ; 6,54-6.51(\mathrm{~d}, 1 \mathrm{H})$; 7.07-7,08 (d, 1H) ; -7.43-7,48 (t, 2H) ; 7,56-7.60 (t, 1H); 7,66-7.68 (d, 1H) ; 8.44-8,46 (d, 1H, $\alpha$-pyridine).

$\underline{\mathrm{RMN}{ }^{13} \mathrm{C}}: 163(2 \mathrm{C}-\mathrm{OMe}) ; 159(\mathrm{C}) ; 156(2 \mathrm{xC}) ; 148(\mathrm{CH})$; $138(2 \times \mathrm{CH}) ; 136(\mathrm{CH}) ; 122(\mathrm{CH}) ; 121(\mathrm{CH}) ; 115(2 \mathrm{xCH})$; $108(2 \mathrm{xCH}) ; 60\left(\mathrm{CH}_{2}\right) ; 59\left(2 \mathrm{CH}_{2}\right) ; 53\left(2 \mathrm{CH}_{3}\right)$.

\section{Procedure for determining the molar conductivity of a complex.}

The measurements are taken at 295K.4 ml of degassed dry acetonitrile are introduced into the measuring cell, and the relative conductivity of the blank is measured (A). The relative conductivity of the sample dissolved in $4 \mathrm{ml}$ of the same solvent is then measured (B). The conductivity of the compound is obtained by subtracting $\mathrm{B}-\mathrm{A}$. The molar conductivity is obtained by the ratio $(\mathrm{B}-\mathrm{A}) /$ Complex concentration.

In the case of Bis-(MeO)TPAFeCl2, the ligand is first introduced into the cell. The metallation is carried out in situ, by adding a stoichiometric quantity of $\mathrm{FeCl} 2$ which is excessively measured.

\section{Common procedure for the metallation of all ligands with ferrous chloride.}

The principle of this reaction is to oppose one equivalent of ferrous chloride to one equivalent of ligand. In practice, a slight excess of ligand (5 to 10\%) is used: this allows complete complexation of the metal, and the excess ligand is easy to remove by washing with ether or THF. This reaction takes place in the absence of Schlenck tube air. The solvents used are all distilled and degassed before use. The filtrations are carried out under overpressure by means of filter cannulas. The standard procedure as published is shown below:0.9 Equivalents of ferrous chloride in solution in THF are added by cannula to a solution of 1.0 equivalent of $\mathrm{Ln}$ ligand in THF.

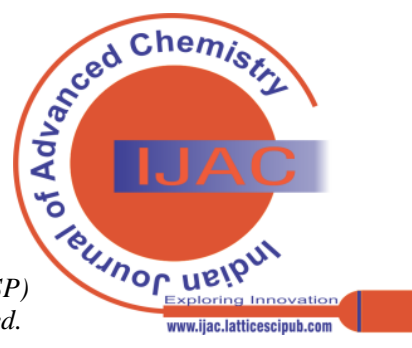


The color quickly turns to orange-yellow, and the reaction medium is kept under stirring for at least 2 hours at room temperature.The solvent is then evaporated in vacuo and the complex extracted with acetonitrile. After filtration and concentration, a yellow-orange solid is obtained by slow addition of diethyl ether. The solid thus obtained can be recrystallized by adding ether to a solution in acetonitrile. After drying with a vacuum pump, the solid is characterized by different techniques. The yields of own products are between 85 and 90\%.

\section{E. General method for the oxidation of} cyclohexane:

$5 \mathrm{~cm} 3$ of acetonitrile and $270 \mu \mathrm{L}$ of cyclohexane are introduced into a Schlenck tube, which are degassed and then $0.005 \mathrm{mmol}$ of the complex is dissolved therein. One to two drops of zinc amalgam are then added, the whole is kept under stirring. The oxygen in a flask is then gradually added to the solution. One to two hours is enough for the mixture to become cloudy, this indicates that the catalyst precipitates at the bottom of the Schlenck tube, the reaction is complete. $4.9 \mu \mathrm{L}$ of acetophenone are added to the solution and the whole is filtered through Celite. Gas chromatographic analysis follows.

\section{RESULTS AND DISCUSSION}

The preparation of the starting products substituted in the position is relatively easy. For 2-bromo-6-methylpyridine, a pressure of $15 \mathrm{mmHg}$ and a temperature of $70-85^{\circ} \mathrm{C}$ gives an oil of white or pale yellow color. At room temperature, this oil becomes more viscous and solidifies in the refrigerator. For the product 2-methoxy-6-methylpyridine [34], the distillation was carried out under $10 \mathrm{mmHg}$ and at $50{ }^{\circ} \mathrm{C}$ giving rise to the recovery of a pale yellow liquid. These products are characterized by their $1 \mathrm{H}$ NMR spectrum.

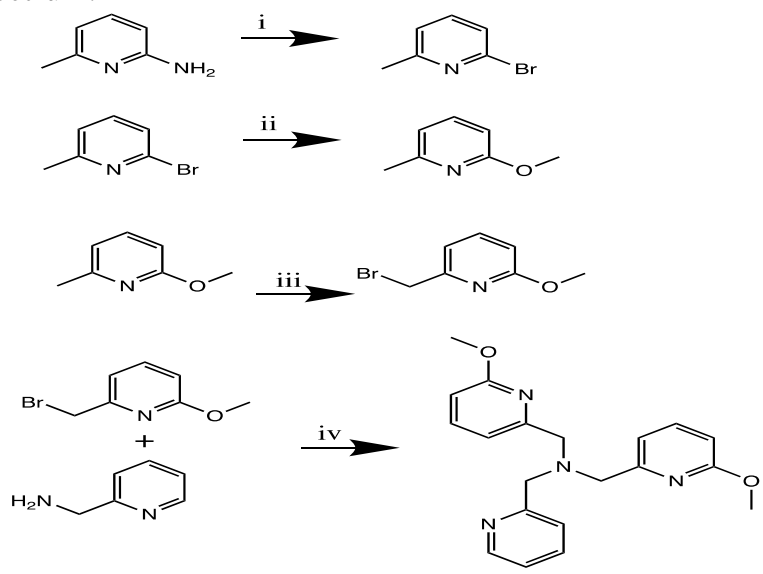

Figure 3: i): $\mathrm{Br}_{2}, \mathrm{HBr}, \mathrm{NaNO}_{2}, \mathrm{H}_{2} \mathrm{O}, 0^{\circ} \mathrm{C}$, ii) : $\mathrm{NaH}$, methanol, DMF, $3 \mathrm{~h}, 100^{\circ} \mathrm{C}$, iii): NBS, AIBN, CCl4, reflux 15h, iv): $\mathrm{Na}_{2} \mathrm{CO}_{3}$ in $\mathrm{CH}_{3} \mathrm{CN}$ reflux for $16 \mathrm{~h}$.

In reality, we know that this trident ligand is not isolable under these conditions, because once formed, it reacts much faster than the starting amine on the 2-methoxy-6bromomethylpyridine derivative, to form the tripod di methoxy [37]. Tripods of formula R2TPA are generally white solids which can be purified by chromatography (the synthesis of MeO2TPA was already described and known in our laboratory [30-39]). They are obtained in the microcrystalline state with yields of around 80\% depending on the preparation (Figure 3). They are characterized by $1 \mathrm{H}$ NMR 13C, spectroscopy, elemental analysis.

\section{A. Complexation of ligand $(\mathrm{MeO})_{2}$ TPA}

The ligands obtained and described above, were metallized with anhydrous ferrous chloride. Anhydrous $\mathrm{FeCl}_{2}$ is a white solid.

$$
\mathrm{L}+\mathrm{FeCl}_{2} \underset{5 \mathrm{~h}, \mathrm{Ar}}{\stackrel{\mathrm{THF} \text { or } \mathrm{CH}_{3} \mathrm{CN}}{\longrightarrow}} \mathrm{LFeCl}_{2}
$$

The reaction is very simple and involves the use of one equivalent of ligand relative to the metal salt, under strictly anhydrous conditions and under an argon atmosphere. The solvents are thus freshly distilled over appropriate desiccants, and before use undergo extensive cryogenic degassing. The methodology used is that known as the "Schlenck technique".In principle, and for practical reasons of further processing, a $10 \%$ excess of ligand with ferrous chloride. The yields of isolated products are generally between 80 and $90 \%$. It is very probable that the reaction is quantitative, but more or less important quantities are lost during the treatment, which is here entirely carried out under an inert atmosphere. In the solid state, the compounds are handled quickly out of the Schlenck tube for a few seconds, for example using an inverted argon funnel.

The solids obtained are generally sufficiently soluble in nitriles to be studied in solution in this type of solvent. The methodology used for their characterization is simple and consists of using the following techniques:

- UV-visible absorption spectroscopy.

- Paramagnetic Nuclear Magnetic Resonance.

- Electrochemical measurements: conductimetry.

- X-ray diffraction on single crystals when possible.

\section{B. UV-visible and conductimetry}

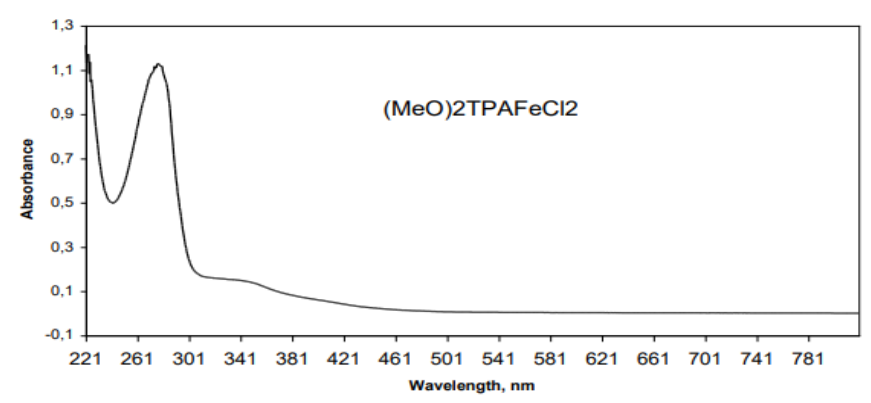

\section{Figure 4 : The UV-visible spectrum for the (MeO) ${ }_{2} \mathrm{TPAFeCl}_{2}$ complex.}

We can see, on spectrum shown on Figure 4, the presence of a rather weak absorption at around $340 \mathrm{~nm}$. Indeed, this wavelength is too short to come from MLCT transition, but it corresponds perfectly to the emergence as described in Table 1 In general, at the onset of oxygenation of octahedral compounds, MLCT absorption still clrearly defined. This is not really visible here. We can easily assume that we are in the presence of a complex whose geometry is of the bipyramid type with a trigonal base.

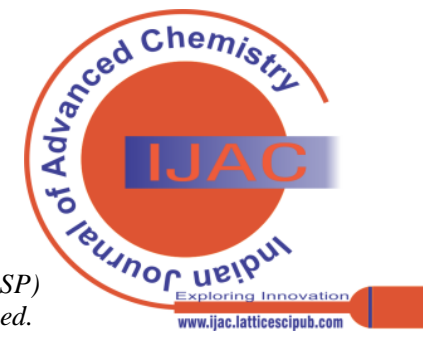


Ferrous Complexes with Bis (Meo) in A-Substituted Tris (Pyridin-2-Ylmethyl) Amine Ligands: Effect of the Bis (Meo) in A- Substituents in Dioxygen Activation and Biomimetic Reactivity

Table 1: the value of absorption in UV-visible spectrum and the conductimetry of complex $\mathrm{MeO}_{2} \mathrm{TPAFeCl}_{2}$.

\begin{tabular}{|c|c|c|}
\hline \multicolumn{2}{|c|}{ UV-visible, $\lambda, \mathrm{nm}\left(\varepsilon, \mathrm{mmmol}{ }^{-1} \cdot \mathrm{cm}^{2}\right)$} & Conductimetry \\
\hline$\pi=5 \pi^{*}$ & MLCT & $\Lambda, \mathrm{Smol}^{-1} . \mathrm{cm}^{2}$ \\
\hline $279.0(8887)$ & $340(1247.7)$ & 29.08 \\
\hline
\end{tabular}

C. $\quad$ RMN 1 H :

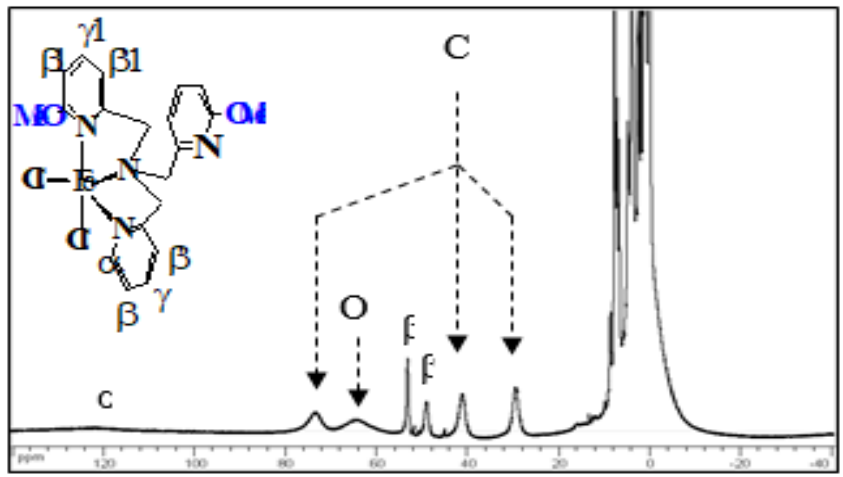

Figure 5 : The $1 \mathrm{H}$ NMR spectrum for the (MeO) ${ }_{2}$ TPAFeCl $_{2}$ complex.

It can be seen on this spectrum that the lines are wide (Figure 5). Qualitatively, this spectrum differs from the previous ones and is quite close to those observed for complexes of bipyramid geometry with a trigonal base, of the $\mathrm{Br}_{2} \mathrm{TPAFeCl}$ type [23]. We were unable to obtain single crystals for this compound. The presumed structure of the resulting compound is the following:<smiles></smiles>

\section{OXYGENATION OF (MEO) $)_{2}$ TPAFECL $_{2}$.}

The oxygenation reaction of (MeO) ${ }_{2} \mathrm{TPAFeCl} 2$ is faster than the previous one (Figure 6). The spectrum stops changing after about 9 hours, and a net absorption is observed at $\lambda=340 \mathrm{~nm}$.

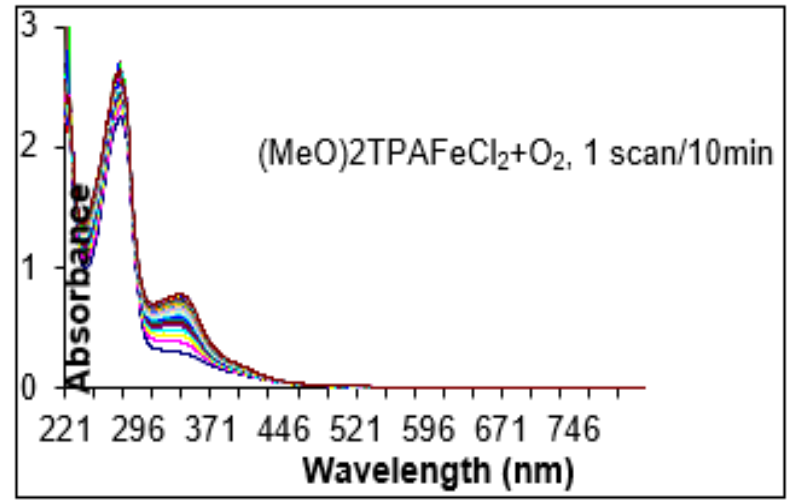

Figure 6 : the oxygenation reaction of the complex (MeO) ${ }_{2} \mathrm{TPAFeCl}_{2}$ fowolled by $\mathrm{UV}$-visible spectroscopy.
The progressive absence of any detecting signals was the main effect of the oxygenation process in $1 \mathrm{H}$ NMR tube. On the other hand, there was a significant amount of free ligand appearing in the tubes, and it was difficult to detect anything else: in fact the oxygenated form precipitated in the NMR tube (Figure 7).

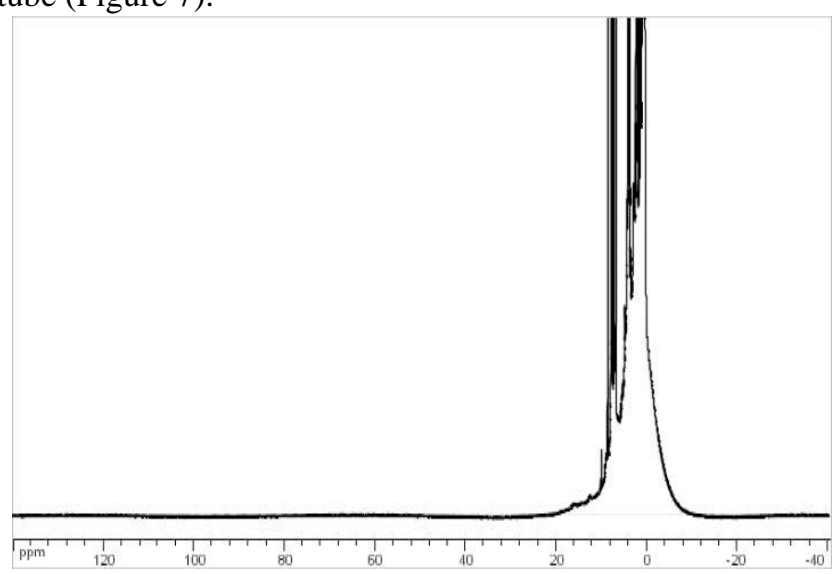

Figure 7 : The 1H NMR spectrum of the oxygenation reaction product of the $(\mathrm{MeO})_{2} \mathrm{TPAFeCl}_{2}$ complex.

\section{STRUCTURE OF THE FINAL COMPOUND}

By covering a solution of oxygenated complex with diethyl ether, a single crystals could be obtained with the following mesh parameters:

Triclinic system, space group P-1. a $=10.3810$ (2) $\AA$, b $=12.3130$ (3) $\AA$, c $=15.3210$ (4) $\AA ; \alpha=97.1020(4)^{\circ}$, $\beta=109.5050(9)^{\circ}, \gamma=109.7150(12)(5)^{\circ}, V=1675.02(7), Z=2$.

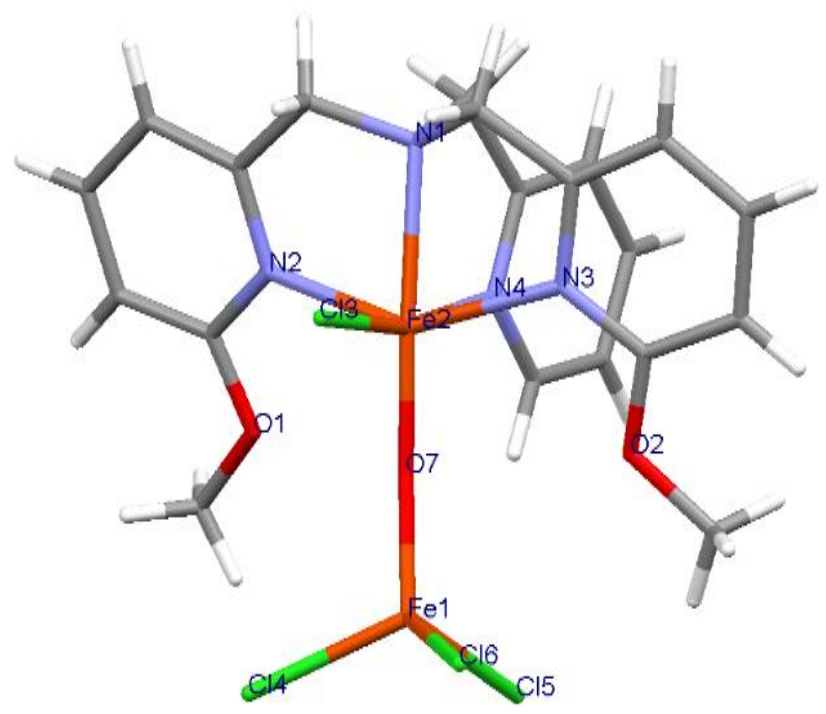

Figure 8: Mercury diagram of the (MeO) ${ }_{2}$ TPAFeClOFeCl $\mathrm{I}_{3}$ complex obtained by oxygenation of the (MeO) ${ }_{2} \mathrm{TPAFeCl}_{2}$ complex.

A Mercury diagram is shown in Figure 8. The compound which crystallizes is a neutral, asymmetric binuclear species comparable to that described previously [43], with the bifluorinated ligand. The main metal-ligand distances and angles are given in Table 2.

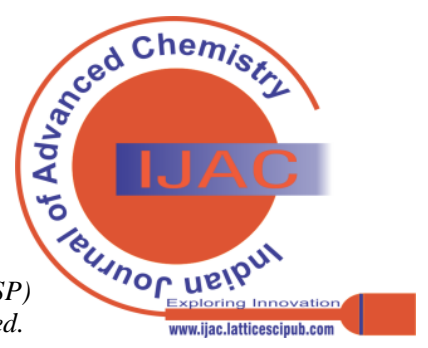


Table 2: Main metal-ligand distances and angles of the (MeO) ${ }_{2} \mathrm{TPAFeClOFeCl}_{3}$.

\begin{tabular}{|c|c|}
\hline \multicolumn{2}{|c|}{$(\mathrm{MeO})_{2} \mathrm{TPAFeClOFeCl}_{3}$} \\
\hline Distances & Angles \\
\hline Fe1 O7 1.755(3)Å & $\begin{array}{l}\text { O7 Fe1 Cl5 } 110.46(10)^{\circ} \\
\text { O7 Fe1 Cl6 } 111.52(11)^{\circ}\end{array}$ \\
\hline Fe1 Cl5 2.2293(12)Å & $\begin{array}{l}\mathrm{Cl} 5 \mathrm{Fe} 1 \mathrm{Cl} 6108.63(6)^{\circ} \\
\mathrm{O} 7 \mathrm{Fe} 1 \mathrm{Cl} 4112.38(11)^{\circ}\end{array}$ \\
\hline Fe1 Cl6 2.2291(14)Å & $\begin{array}{l}\mathrm{Cl} 5 \mathrm{Fe} 1 \mathrm{Cl} 4107.20(5)^{\circ} \\
\mathrm{Cl} 6 \mathrm{Fe} 1 \mathrm{Cl} 4106.45(6)^{\circ}\end{array}$ \\
\hline Fe1 Cl4 2.2395(13)Å & $\begin{array}{l}\text { O7 Fe2 N4 95.15(13) } \\
\text { O7 Fe2 N2 104.27(14) }\end{array}$ \\
\hline Fe2 O7 1.766(3)Å & $\begin{array}{l}\text { N4 Fe2 N2 85.24(12) } \\
\text { O7 Fe2 N3 106.06(14) }\end{array}$ \\
\hline Fe2 N4 2.148(3)Å & $\begin{array}{l}\text { N4 Fe2 N3 81.34(13) } \\
\text { N2 Fe2 N3 } 147.73(12)^{\circ}\end{array}$ \\
\hline Fe2 N2 2.204(3)Å & $\begin{array}{l}\text { O7 Fe2 N1 173.09(13) } \\
\text { N4 Fe2 N1 78.11(12) }\end{array}$ \\
\hline Fe2 N3 2.211(3)Å & $\begin{array}{l}\text { N2 Fe2 N1 73.88(12) } \\
\text { N3 Fe2 N1 } 74.69(12)^{\circ}\end{array}$ \\
\hline Fe2 N1 2.254(3)Å & $\begin{array}{l}\text { O7 Fe2 Cl3 97.84(10) } \\
\text { N4 Fe2 Cl3 } 166.85(9)^{\circ}\end{array}$ \\
\hline Fe2 Cl3 2.3322(11)Å & N2 Fe2 Cl3 93.48(9) ${ }^{\circ}$ \\
\hline & $\begin{array}{l}\text { N3 Fe2 Cl3 93.09(9) } \\
\text { N1 Fe2 Cl3 88.95(9) } \\
\text { Fe1 O7 Fe2 } 167.0(2)^{\circ} \\
\text { C11 N1 Fe2 } 106.6(2)^{\circ} \\
\text { C19 N1 Fe2 } 106.2(2)^{\circ} \\
\text { C12 N1 Fe2 } 110.9(2)^{\circ} \\
\text { C15 N2 Fe2 } 125.8(3)^{\circ} \\
\text { C18 N2 Fe2 } 115.8(3)^{\circ}\end{array}$ \\
\hline
\end{tabular}

\section{REACTIVITY IN THE PRESENCE OF SUBSTRATE.}

The oxygenation mechanism of the complexes, shows that at some point an intermediate $\quad \mathrm{Fe}^{\text {(IV) }}$ - oxo species is formed. This species is very oxidizing, during the reaction in the absence of substrate, it reacts with a complex molecule to form a $\mu$-oxo diferric species. It would therefore be conceivable that such species, in the presence of cyclohexane as substrate, is capable of transferring oxygen to lead to the formation of an oxidized substrate.

The oxidation of cyclohexane to cyclohexanone has already been studied with ferrous chloride salt and TPA complexes. Therefore, the obtained complexes were reacted with cyclohexane in the presence of $\mathrm{O}_{2}$. We used zinc amalgam as the $\mathrm{Fe}^{\text {(III) } / \mathrm{Fe}}{ }^{\text {(II) }}$ reducing agent to regenerate reactive species during the reaction. In a schlenck tube, we prepared a solution of known concentration of complex dissolved in acetonitrile, we then added cyclohexane, a few drops of zinc amalgam, with bubbling oxygen. After one to two hours, a grayish solution is obtained, the acetophenone is added in a known quantity and the whole is filtered through celite. Acetophenone is used as a reference for gas chromatography analysis. The first signal appears at 4.1 minutes and corresponds to the acetonitrile peak, which is the most intense. Then a few seconds later follows the cyclohexane signal, a low intensity peak. At around 6.6 minutes, the appearance of cyclohexanone is observed, a very weak peak and at the end of 11.6 minutes the reference signal, acetophenone, appears. The relationship below makes it possible to calculate the concentration of cyclohexanone and therefore the turn over number (TON): [cyclohexanone] = 1.2 [acetophenone] * Aire (cyclohexanone) / Aire (acetophenone)

TON $=$ [cyclohexanone $/$ [catalyst $]$

In the Table below, are listed the results obtained:

Table 3: the conversion turnover (TON) of cyclohexane to cyclohexanone and cyclohexane to cyclohexanol.

\begin{tabular}{|l|c|c|c|c|}
\hline & $\mathrm{FeCl}_{2}$ & $\mathrm{TPAFeCl}_{2}$ & $\mathrm{MeOTPAFeCl}_{2}$ & $(\mathrm{MeO}) 2 \mathrm{TPAFeCl}_{2}$ \\
\hline TON & $=0.4$ & $=8$ & $=29$ & $=40$ \\
\hline
\end{tabular}

VI.

MECHANISTIC CONSIDERATIONS

The ferric series $\mu$-oxo type complexes constitute a class of derivatives well known in inorganic chemistry. Aside from the chemistry of porphyrins, their mechanism of formation is not fully studied. They are generally obtained by mixing ferric salts $\mathrm{FeCl}_{3} \mathrm{nH}_{2} \mathrm{O}$, or even $\mathrm{Fe}\left(\mathrm{ClO}_{4}\right)_{3} \mathrm{n} \mathrm{H}_{2} \mathrm{O}$ with the ligands, most of the time in a protic medium or in the presence of alcohols, without taking special precautions. How is the $\mu$-oxo bridge created then? Is it by deprotonation of hydroxo ligands (and by what base)?, by oxidation of bound hydroxides [30,45-52]?, or is air oxygen involved? The question has been persistent for many years, without any concluding results.From ferrous derivatives and molecular oxygen, a simple mechanism was postulated some thirty years ago in porphyrin chemistry [31-50-52]. It is better known as the "autoxidation of ferroporphyrins" mechanism. This mechanism as published is reproduced in Figure 9.One equivalent of dioxygen reacts with one equivalent of ferrous derivative, to give the adduct product $\mathrm{B}$. The later will react with the starting product via the free doublet of coordinated oxygen. The $\mu$-peroxo $\mathrm{C}$ species is formed, and undergoes a homolytic cleavage which leads to the formation of the oxo-ferryl species D. D reacts again on A to form the final $\mu$-oxo compound E. Four equivalents of complex were necessary to cut one equivalent of the oxygen molecule.

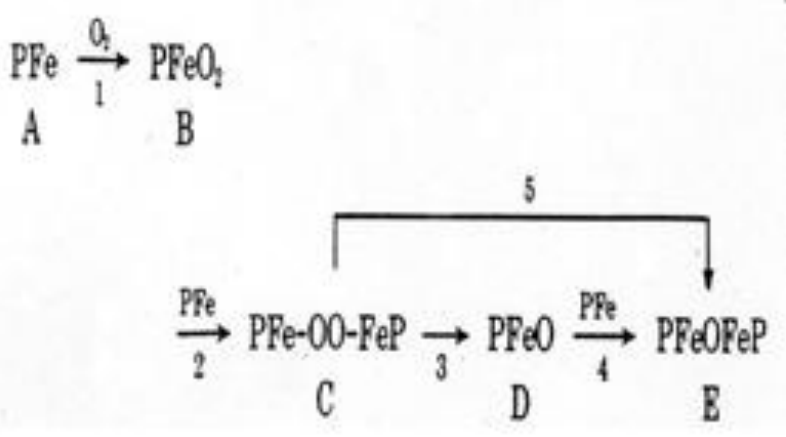

Figure 9 : diagram known as autoxidation of porphyrins.

The stable forms are A and E. Only the C form could be detected during this process.A mechanism similar to that described in porphyrin chemistry can be postulated. It is presented in Figure 10. The stable species detected after oxygenation are indicated on a gray background: $\mu$-oxo derivatives, symmetric, asymmetric, $\mu$-dichloro derivative.

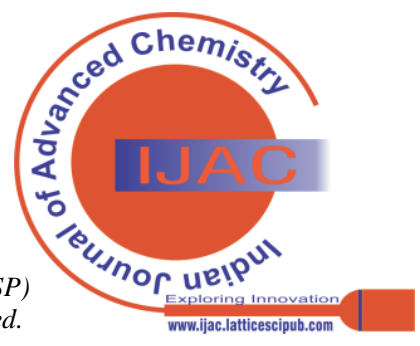



(Meo) in A- Substituents in Dioxygen Activation and Biomimetic Reactivity

The formation of $\mu$-dichloro species can be explained by the presence of background salt, that could lead to complex dinucleation. The process described in Figure 10 is likely to generate cationic species, and therefore increase the ionic strength of the medium, thus making chloride ions more labile. For technical reasons, we were unable to carry out precise measurements of oxygen uptake by our complexes.

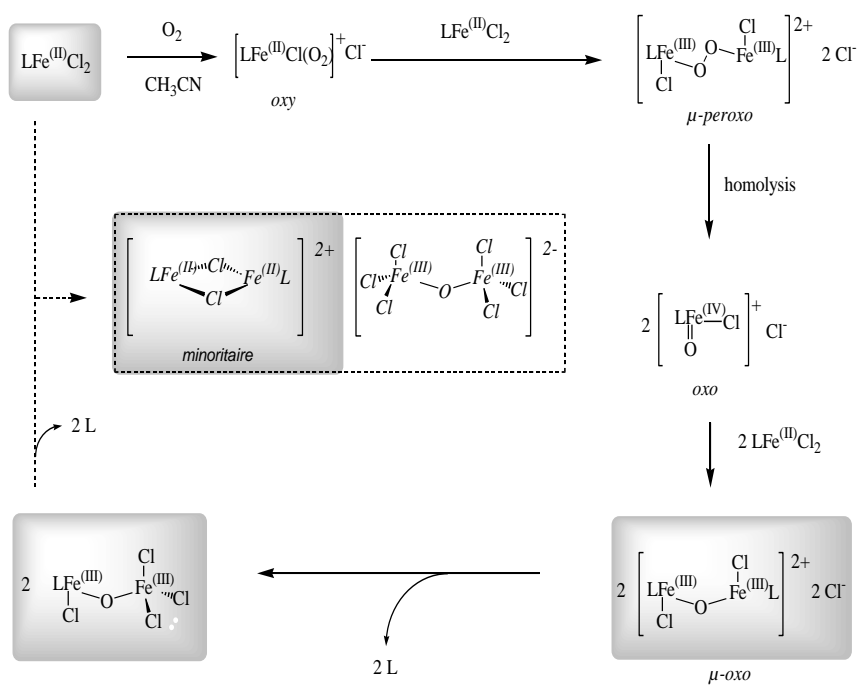

Figure 10 : Adaptation of the autoxidation scheme of complexes in the TPA series.

\section{CONCLUSION}

In the present report, a series of TPA ligands substituted by methoxy groups was synthesized, characterized and complexed with $\mathrm{FeCl}_{2}$. This type of ligands is electrodonner. The desire to create such ligands was not trivial, in fact, the initial purpose was to demonstrate and to study reactivity between electrodonner and electro-deficient ligand [37-46], which has been fully investigated, this will demonstrate the different rate of $\mathrm{O}_{2}$ coordination on the complex. The prepared complexes were characterized by different spectroscopic techniques, thus making it possible to predict their geometry in both solution and solid states for $(\mathrm{MeO})_{2} \mathrm{TPAFeCl}_{2}$ and $\mathrm{MeOTPAFeCl}{ }_{2}$ as shown previously [53]. Furtheremore, the reactivity of the complexes in presence of substrate (cyclohexane) was studied, this reaction was in fact catalytic, indeed several cycles are observed, and clean since it leads to the formation of ketone not alcohol. From results in Table 2, we should have obtained alcohol since we assumed the oxidizing species to be the intermediate Fe ${ }^{\text {(IV) }}$-oxo. Thus, mechanistic studies are to be expected [39-49].

\section{REFERENCES:}

1. Heidi, E.; Bjorgo. E.; Flatmark T.; and Stevens R. C.; Biochimistry 2000, 39, 2208-2217. [CrossRef]

2. Malek, Z.S.; Sage D.; Pevet, P.; Raison, S.; Endocrinology 2007, 148 (11), 5165-5173 [CrossRef]

3. Malek, Z.S.; Dardente, H.; Pevet, P.; Raison, S.; European Journal of Neuroscience 2005, 22 (4), 895-901. [CrossRef]

4. Malek, Z.S.; Pevet, P.; Raison, S.; Neuroscience 2004, 125 (3), 749758. [CrossRef]

5. Malek, Z.S.; Labban, L.; The International Journal of Neuroscience, 2020, 1-7.

6. Malek, Z.S.; Labban, L.; European Journal of Pharmaceutical and Medical Research 2019, 6 (11), 527-532. porphyrins to the chemistry of simple dichloroferrous

7. Malek, Z.S.; Journal of AlBaath University 2018, 40 (4), 39-62

8. Malek, Z.S.; Tishreen University Journal for Research and Scientific Studies, 2018, 40

9. Kappock, T. J; Caradonna, J. P.; Chem.Rev. 1996, 96, 2659-2756. [CrossRef]

10. Solomon, E. I.; Brunold, T. C.; Mindy I. D.; Kemsley, J. N.; Sang-Kyu Lee.; Lehnert, N.; Neese, F.; Skulan, A. J.; Yi-Shan Y.; and Jing Z.; Chem.Rev. 2000, 100, 235-349. [CrossRef]

11. Goodwill, K. E.; Sabatier, C.; and Stevens, R. C.; Biochemistry 1998, 37, 13437-13445. [CrossRef]

12. Wang Lin.; Erlandsen, H.; Haavik, J.; Knappskog, P. M.; and Stevens R. C , Biochemistry 2002, 41, 12569-12574. [CrossRef]

13. Nordlund P.; in Handbook of Metalloproteins (Eds.: I. Bertini,A. Sigel, H. Sigel), Marcel Dekker, New York, 2001, pp. 461 -570. [CrossRef]

14. Xia, T.; Gray, D. W. ; Shiman, R. J.; Biol. Chem. 1994, 269, $24657-$ 24665. [CrossRef]

15. Francisco W. A.; Tian G.; Fitzpatrick P. F.; and Klinman J. P , J. Am. Chem. Soc.;1998, 120, 4057 -4062. [CrossRef]

16. Arianna B.; Margareta R.A.; Per E.M .S.; Chem. Eur. J. 2003, 9,106115

17. Flatmark T.; Stevens R. C.; Chem. Rev. 1999, 99, 2137-2160 [CrossRef]

18. Kemsley, J. N. ; Mitic, N.; Loeb-Zaleski, K.; Cradonna, J. P.; Solomon, E. I.; J. Am. Chem. Soc. 1999, 121, 1528-1536. [CrossRef]

19. Dix, T. A.; Kuhn, D. M.; Benkovic, S. J.; Biochemistry 1987, 26, 3353-3361. [CrossRef]

20. Hillas, P. J.; Fitzpatrick, P. F.; Biochemistry 1996, 35, 6969-6975. [CrossRef]

21. Dix, T. A.; Bollag, G. E.; Domanico, P. L.; Benkovic, S. J.; Biochemistry 1985, 24, 2955-2958. [CrossRef]

22. Gardner, H. W.; Biochim. Biophys. Acta 1991, 1084, 221-239. [CrossRef]

23. Mandon, D., Machkour, A., Goetz, S., Welter, R., Inorg. Chem., 2002, 41, 5364 - 5372. [CrossRef]

24. Thallaj, N., Machkour, A., Mandon, D., Welter, R., New. J. Chem., 2005, 29, 1555 - 1558[CrossRef]

25. Machkour, A., Mandon, D., Lachkar, M., Welter, R., Inorg. Chim. Acta, 2005, 358, 839 - 843. [CrossRef]

26. Bioinorganic Chemistry: A short course. Roat-Malone, R.M., Wiley Interscience. 2002.

27. Solomon, E. I., Brunold, T. C., Davis, M. I., Kemsley, J. N., Lee, S. K., Lehnert, N., Neese, F., Skulan, A. J., Yang, Y. S., Zhou, J., Chem. Rev., 2000, 100, 235-349. [CrossRef]

28. Coordination Chemistry Reviews 200-202, 2000, 443-485[CrossRef]

29. Kryatov, S.V., Rybak-Akimova, E.V., MmacMurdo, V.L., Que, L.Jr., Inorg Chem 2001, 40, 2220-2228 and many references herein. [CrossRef]

30. Michael P .Jensen ,Steven J.Lange, Mark, Emily L.que And Lawrence Que , Jr. JACS ,2003, 125, 2113-2128. [CrossRef]

31. Lehnert, N., Ho, R.Y.N., Que, L.Jr., Solomon, E.I., J. Am Chem Soc., 2001, 123, 8271-8290. [CrossRef]

32. Costas, M., Tipton A.K., Chen, K., Jo, D.H., Que, L.Jr, J. Am Chem Soc., 2001, 123, 6722-6723. [CrossRef]

33. Jo, D.H., Chiou, Y.M., Que, L.Jr., J.Am.Chem.Soc., 2001, 40, 31813190. [CrossRef]

34. Chiou, Y.M., Que, L.Jr., J.Am.Chem.Soc., 1995, 117, 3999-4013. [CrossRef]

35. Zang, Y., Que, L.,Jr., Inorg Chem 1995, 34, 1030-1035. [CrossRef]

36. Mandon, D., Machkour, A., Goetz, S., Welter, R., Inorg. Chem 2002., Vol.41,No.21, [CrossRef]

37. Machkour, A., Mandaon, D., Welter, R., Inorg. Chem. 2004, 43, 4, 1545-1550[CrossRef]

38. Thallaj, N. K. Damascus University Journal for Basic Sciences. 34 (1) 2018

39. Thallaj. N. K. Journal of AlBaath University (39) 2017.

40. Thallaj. N. K. Tishreen University Journal for Research and Scientific Studies 38 (6) 2016.

41. N. K. Thallaj, P.Y. Orain, A. Thibon, M. Sandroni, R. Welter and D. Mandon, Inorg. Chem. 2014, 53 (15), 7824-7836. [CrossRef]

42. A. Wane, N. K. Thallaj, and D. Mandon Chem. Eur. J. 2009, 15, 10593 -10602. [CrossRef]

43. N. K. Thallaj, O. Rotthaus, L. Benhamou, N. Humbert, M. Elhabiri, M. Lachkar, R. Welter, A.M. Albrecht-Gary, and D. Mandon, Chem. Eur. J. 2008, 14(22) 6742-6753. [CrossRef]

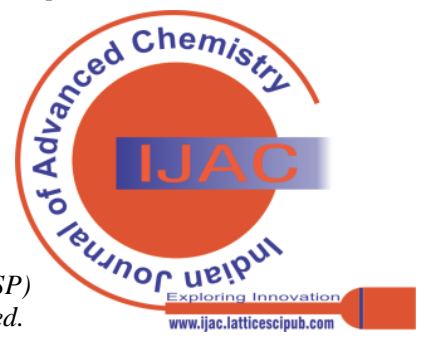


44. N. K. Thallaj, J. Przybilla, R. Welter and D. Mandon, J. Am. Chem. Soc. 2008, 130, 2414-2415. [CrossRef]

45. N. K. Thallaj, D. Mandon and K. A. White, Eur. J. of Inorg. Chem., 2007, 44-47. [CrossRef]

46. Machkour, N. K. Thallaj, L. Benhamou, M. Lachkar and D. Mandon, Chem. Eur. J., 2006, 12, 6660 - 6668. [CrossRef]

47. N. K. Thallaj, A. Machkour, D. Mandon and R. Welter, New J. Chem., 2005, 29, 1555-1558. [CrossRef]

48. V. Caprio, J. Mann, J. Chem. Soc., Perkin Trans. 1, 1998, 3151-3155. [CrossRef]

49. Da Mota, M. M.; Rodgers, J.; Nelson, S. M.; J. Chem. Soc. (A). 1969, 2036-2044. [CrossRef]

50. Andris, E.; Navrátil, R.; Jasik, J.; Puri, M.; Costas, M.; Que, L., Jr.; Roithová, J. J. Am. Chem. Soc. 2018, 140, 14391-14400[CrossRef]

51. Cutsail III, G.; Banerjee, R.; Zhou, A.; Que, L., Jr.; Lipscomb, J. D.; DeBeer, S. J. Am. Chem. Soc. 2018, 140, 16807-16820. [CrossRef]

52. Fan, R.; Serrano-Plana, J.; Oloo, W. N.; Draksharapu, A.; DelgadoPinar, E.; Company, A.; Martin-Diaconescu, V.; Borrell, M.; LloretFillol, J.; García-España, E.; Guo, Y.; Bominaar, E. L.; Que, L., Jr.; Costas, M.; Münck, E. J. Am. Chem. Soc. 2018, 140, 3916-3928. [CrossRef]

53. Thallaj, N.; International journal of applied chemistry and biological sciences 2021, 2 (4), 65-77.

\section{AUTHOR PROFILE:}

Dr. Nasser K Thallaj, Assistant Professor of Chemistry at Faculty of Pharmacy, Al Rasheed Private University in Damascus, Syria. Dr. Thallaj has been teaching chemistry in different Syrian university and he was president of Al Jazeera Private University in Syria

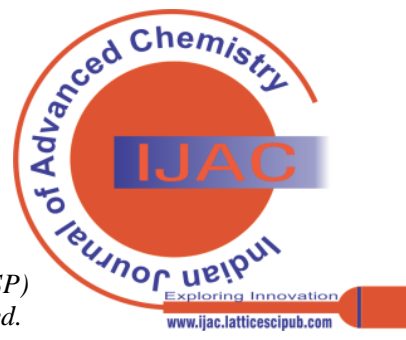

